\title{
Peningkatan Pemahaman Kesehatan pada Ibu hamil dalam Upaya Pencegahan COVID-19
}

\author{
Juneris Aritonang $^{1 *}$, Lolita Nugraeny ${ }^{2}$, Sumiatik$^{2}$, Ronni Naudur Siregar ${ }^{1}$ \\ ${ }^{1}$ Program Studi Profesi Bidan, Universitas Sari Mutiara Indonesia, Jalan Kapten Muslim No. 79, Medan, \\ 20123 \\ ${ }^{2}$ Fakultas Kesehatan Universitas Haji Sumatera Utara, Jalan RS. Haji Medan Estate, Medan, 20237 \\ *Email Korespondensi: june_30ops@yahoo.co.id
}

\begin{abstract}
Abstrak
Ibu hamil tercatat salah satu kelompok rentan resiko terinfeksi COVID-19 dikarenakan pada masa kehamilan terjadinya perubahan fisiologi yang mengakibatkan penurunan kekebalan parsial. Studi awal didapati banyak ibu hamil tidak melaksanakan protokol kesehatan dalam keseharianya dan hasil wawancara, ibu hamil menunjukkan kecemasan pada kehamilannya selama era pandemi COVID-19. Kecemasan yang di tunjukkan ibu hamil tersebut tidak sesuai atau berbanding terbalik dengan perilaku ibu hamil dalam kepatuhan melaksanakan protokol kesehatan selama ini. Perlu dilakukan suatu perubahan melalui kegiatan pemberian pendidikan kesehatan yang bertujuan untuk meningkatkan pemahaman ibu hamil dalam upaya pencegahan COVID-19 dan juga mengurangi kecemasan ibu hamil selama era pandemi COVID-19. Kegiatan ini dilakukan di Balai pengobatan Swasta Mariana, Deli Serdang Sumatera Utara. Pesertanya merupakan ibu hamil yang tercatat melakukan ante natal care (ANC) di Balai Pengobatan Swasta Mariana berjumlah 37 orang. Kegiatan ini berupa penyuluhan, demonstrasi dan diskusi dengan para peserta. Pemahaman dan kecemasan peserta dinilai melalui hasil pengisian kuesioner oleh peserta. Penilaian pengisian kuesioner dilakukan sebelum dan sesudah kegiatan ini berlangsung ditambah dengan pada saat sesi diskusi antara peserta dan TIM. Hasil yang didapati setelah dilakukan penyuluhan adalah adanya peningkatan pemahaman ibu hamil tentang COVID-19 dan penurunan kecemasan ibu hamil selama kehamilan di era pandemi COVID-19. Kegiatan ini dapat dijadikan sebagai upaya pencegahan COVID-19 pada masyarakat secara umum dan pada kelompok ibu hamil khusunya.
\end{abstract}

Kata kunci: Pemahaman; ibu hamil; pencegahan; kecemasan; COVID-19

\begin{abstract}
Pregnant women are listed as one of the vulnerable groups at risk of being infected with COVID-19 because during pregnancy there are physiological changes that result in a partial decrease in immunity. Initial studies found that many pregnant women did not implement health protocols in their daily lives and the results of interviews showed that pregnant women showed anxiety about their pregnancies during the COVID-19 pandemic era. The anxiety shown by pregnant women is not appropriate or inversely proportional to the behavior of pregnant women in implementing health protocols so far. It is necessary to make changes through health education activities aimed at increasing understanding of pregnant women in efforts to prevent COVID19 and also reduce anxiety of pregnant women during the COVID-19 pandemic era. This activity was carried out Balai Pengobatan Swasta Marianan Deli Serdang, North Sumatra. The participants were pregnant women who were recorded as having ante natal care (ANC) at the Balai Pengobatan Swasta Marianan Deli Serdang, totaling 37 people.This activity is in the form of counseling, demonstrations and discussions with the participants. Participants' understanding and anxiety were assessed through the results of filling out a questionnaire by the participants. The questionnaire filling assessment was carried out before and after this activity was carried out coupled with the discussion session between the participants and the team. The results obtained after counseling were an increase in understanding of pregnant women about COVID-19 and a decrease in anxiety for pregnant women during pregnancy in the era of the COVID-19 pandemic. This activity can be used as an effort to prevent COVID-19 in the community in general and for pregnant women in particular.
\end{abstract}

Keywords: Knowledge; pregnant women; prevention; anxiety; COVID-19 
Format Sitasi: Format Sitasi: Aritonang, J., Nugraeny, L., Sumiatik, Siregar, R.N. (2020). Peningkatan Pemahaman Kesehatan pada Ibu Hamil dalam Upaya Pencegahan COVID-19 Jurnal Solma, 09(2), 261-269. Doi: http://dx.doi.org/10.22236/solma.v9i2.5522

Diterima: 01 September 2020 | Revisi: 05 September 2020 | Dipublikasikan: 30 Oktober 2020

(c) 2020 Oleh authors. Lisensi Jurnal Solma, LPPM-Uhamka, Jakarta. Artikel ini bersifat open access yang didistribusikan di bawah syarat dan ketentuan Creative Commons Attribution (CC BY) license. (http://creativecommons.org/licenses/by/4.0/).

\section{PENDAHULUAN}

Infeksi Novel Coronavirus Disease 2019 (COVID-19) merebak sejak tahun 2019, World Health Organization (WHO) melaporkan virus ini pertama kali ditemukan di Wuhan (Qiao, 2020). Seluruh belahan di dunia kini melaporkan angka kejadian penduduk yang positif terinfeksi COVID-19 termasuk di Indonesia. Situasi berkembang menjadi darurat kesehatan masyarakat secara global (Yang et al., 2020). Terbukti dari 216 negara tercatat yang terkonfirmasi positif COCID-19 sebanyak 17.660.523 dan kasus yang meninggal 680.894 data 28 Agustus tahun 2020 (Gugus Tugas Penanganan COVID-19 RI, 2020). Indonesia melaporkan adanya dua kasus positif untuk pertama kalinya (Maret 2020) (Pradana et al., 2020). Di Indonesia tercatat terjadi peningkatan kasus terkonfirmasi positif sebanyak 3003 menjadi 165.887, yang sembuh mengalami peningkatan sebanyak 2325 menjadi 120.900, dan yang meninggal mengalami peningkatan sebanyak 105 menjadi 7.169 kasus (Gugus Tugas Penanganan COVID-19 RI, 2020).

Pemerintah Indonesia melalui Keputusan Presiden republic Indonesia Nomor 12 Tahun 2020 menetapkan bencana non alam penyebaran COVID-19 sebagai bencana nasional dikarenakan bencana ini berdampak meningkatnya jumlah korban jiwa, ekonomi dan luasnya wilayah yang terkena bencana ini (Kementrian Kesehatan Republik Indonesia, 2020). Oleh sebab itu disejumlah negara termasuk pemerintah Indonesia melakukan pencegahan dan pengendalian infeksi COVID-19 dan yang menjadi perhatian utama adalah pada kelompok rentan yang potensi resiko lebih besar salah satu diantaranya adalah kelompok ibu hamil (Qiao, 2020).

Ibu hamil tercatat salah satu kelompok rentan resiko terinfeksi COVID-19 dikarenakan pada masa kehamilan terjadinya perubahan fisiologi yang mengakibatkan penurunan kekebalan parsial (Liang \& Acharya, 2020) dan dapat menyebabkan dampak yang serius bagi ibu hamil. Informasi tentang COVID-19 hingga saat ini masih sangat terbatas termasuk data ibu hamil terkonfirmasi positif COVID-19 belum dapat disimpulkan di Indonesia (Pradana et al., 2020). Hasil penelitian dari 55 wanita hamil dan 46 neonatus yang terinfeksi COVID-19 tidak dapat dipastikan adanya penularan vertikal dan belum diketahui apakah meningkatkatkan kasus keguguran dan kelahiran mati (Dashraath et al., 2020). Hasil penelitian yang dilakukan oleh (Schwartz, 2020) didapati 37 ibu hamil yang terkonfirmasi COVID-19 melalui PCR tidak ditemukan pneumonia berat dan atau kematian maternal, diantara 30 neonatus yang dilahirkan tidah ditemukannya kasus yang terkonfirmasi COVID-19.

Berbeda pada wabah SARS dan MERS (wabah korona virus sebelumnya), didapati ibu hamil memiliki resiko kematian tinggi massalah lainnya seperti abortus spontan, premature, Intra Uterin Growth Retardation (IUGR), ketuban pecah dini (KPD), janin 
dengan takikardia, gawat janin (Pradana et al., 2020). Pada COVID-19 peningkatan resiko yang ada pada kasus SARS dan MERS belum dapat diketahui secara pasti (Luo \& Yin, 2020). Dalam analisis laporan yang ditulis oleh (31) dari 38 ibu hamil dengan COVID-19, dengan usia kehamilan bervariasi antara 30-40 minggu, 37 orang di antaranya dikonfirmasi melalui tes PCR, tidak ditemukan adanya pneumonia berat atau kematian maternal. Diantara 30 neonatus yang dilahirkan, tidak ditemukan adanya kasus yang terkonfirmasi dengan COVID-19.

Pada situasi pandemi COVID-19 ini, pemerintah membuat kebijakan adanya pembatasan hampir pada semua layanan rutin salah satu contohnya adalah pelayanan kesehatan maternal dan neonatal dan fasilitas pelayanan kesehatan lainnya. Timbulnya kecemasan dari ibu hamil sehingga menunda melaksanakan pemeriksaan kehamilan (Kementrian Kesehatan Republik Indonesia, 2020). Terjadinya peningkatan kecemasan ibu hamil pada era pandemi COVID-19 disebabkan faktor kurangnya pengetahuan ibu hamil mengenai COVID-19 dan cara pencegahannya. Berbagai upaya telah dilakukan pemerintah dan lembaga lainnya untuk mensosialisasikan mengenai COVID-19, tetapi masih banyak masyarakat yang belum memahaminya secara keseluruhan. Hal tersebut juga disebabkan banyaknya informasi palsu (hoax) yang beredar dan diyakini di tengah masyarakat mengenai informasi COVID-19 mulai dari asal virus hingga kebijakan yang diambil oleh pemerintah dalam pengendalian COVID-19 (Saputra, 2020).

Kecemasan yang dialami oleh ibu hamil dapat menurunkan imun ibu hamil tersebut sehingga dapat semakin rentan terinveksi COVID-19. Kegiatan pengabdian kepada masyarakat ini di laksanakan di Balai Pengobatan Swasta Mariana yang terletak di Kecamatan Sunggal Kabupaten Deli Serang, Sumatera Utara. Sumatera Utara per tanggal 30 Agustus 2020 melaporkan jumlah kasus terkonfirmasi COVID-19 berjumlah 6.769 dan 861 konfirmasi COVID-19 berasal dari Kabupaten Deli Serdang (SUMUT, 2020). Beberapa hal yang melatar belakangi dilakukannya kegiatan ini diantaranya tingginya jumlah terkonfirmasi COVID-19 di kabupaten ini, selain itu didapati pada studi awal dilakukan sebelum kegiatan ditemukannya masih banyak ibu hamil ketika beraktivitas di luar rumah tidak sesuai dengan protokol kesehatan seperti tidak memakai masker, masih ngobrol dengan tetangga tanpa menjaga jarak, dan sesekali tanpak masih ikut dalam kerumunan.

Pada survey awal dilakukan wawancara singkat kepada ibu hamil yang datang ke Balai Pengobatan Mariana untuk Ante Natal Care (ANC) berjumlah 10 orang, dari 10 orang tersebut didapati 80 persen belum mengetahui dengan baik mengenai COVID-19 termasuk protokol kesehatan yang harus dilaksanakan dalam mencegah terinfeksinya COVID-19. Seluruh ibu hamil tersebut merasa cemas akan kehamilannya selama era pandemi COVID19. Pada disaat studi pendahuluan juga, masih ditemukan ibu hamil datang ke Balai Pengobatan Swassta Mariana tanpa menggunakan masker, dan pihak balai pengobatan memberikan masker kepada ibu tersebut agar dapat diberikan pelayanan kesehatan. Ada juga ibu hamil memakai masker dengan teknik yang tidak tepat.

Dari latar belakang yang telah diuraikan tersebut, tim pelaksana kegiatan pengabdian masyarakat memutuskan untuk melaksanakan kegiatan dengan judul "Peningkatan Pemahaman Ibu hamil Dalam Upaya Pencegahan Covid-19”. Kegiatan ini dilakukan dengan pemberian pendidikan kesehatan melalui penyuluhan kepada ibu hami yang berkunjung ke 
Balai Pengobatan Swasta Mariana. Kegiatan ini bertujuan untuk meningkatkan pemahaman ibu hamil tentang COVID-19 untuk mencegah terinfeksi COVID-19 dan mengurangi kecemasan ibu hamil selama pandemi COVID-19.

\section{MASALAH}

Tim pengabdian masyarakat pada saat studi pendahuluan menemukan seluruh ibu hamil yang diwawancari merasa cemas pada kehamilannya selama pandemi COVID-19. Ada ibu yang mengatakan cemas jika terinfeksi COVID-19 dan menularkan ke janin dalam kandungannya, kecemasan mengenai pada saat persalinan nanti apakah aman dilaksanakan di rumah maupun di pelayanan kesehatan, dan ada yang merasa cemas jika nanti bayinya lahir dan proses menyusui pada masa pandemi COVID-19.

Kecemasan yang ditunjukkan oleh ibu hamil yang diwawancarai tersebut tidak sesuai atau berbanding terbalik dengan perilaku ibu hamil dalam kepatuhan melaksanakan protokol kesehatan kesehariannya. Terbukti pada saat studi pendahuluan, terdapat empat ibu yang berkunjung ke Balai Pengobatan Swasta Mariana tidak menggunakan masker dengan alasan lupa dan jarak antara rumah dan klinik cukuplah dekat. Petugas kesehatan tetap memberikan pelayanan kesehatan dengan terlebih dahulu memberikan masker kepada ibu hamil dan menganjurkan mencuci tangan efektif kepada ibu hamil sebelum masuk ke ruang periksa.

Ketidak sesuaian antara rasa cemas dalam menghadapi pandemi COVID-19 dengan perilaku dalam upaya pencegahan terinfeksi COVID-19 disebabkan kurangnya pemahaman ibu hamil tentang COVID-19 dan bagaimana upaya pencegahan terinfeksi COVID-19 dan juga adanya informasi palsu (hoax) yang diterima oleh para ibu hamil.

Tantangan yang dihadapi pada saat kegiatan pengabdian masyarakat bukanlah suatu tantangan yang berat, lebih ke arah penataan tempat dilaksanakan penyuluhan sesuai dengan protokol kesehatan yang dianjurkan diantaranya menjaga jarak antar peserta. Setelah dilakukan diskusi antar tim kegiatan pengabdian masyarakat dan pimpinann Balai Pengobatan Swasta Mariana sebagai lokasis kegiatan maka, tim membagi kegiatan menjadi 4 kelompok guna mengurangi kerumunan (membatasi peserta menjadi 1 kali penyuluhan hanya berjumlah 10-15 orang saja). Kebutuhan masyarakat/mitra adalah informasi yang tepat tentang COVID-19 secara umum dan cara pencegahannya secara khusus. Sehingga setelah kegiatan ini berlangsung Ibu hamil sebagai kelompok rentan mengalami peningkatan pemahaman upaya pencegahan Covid-19, sehingga mengurangi kecemasan ibu hamil selama pandemi COVID-19 dan ibu hamil tetap sehat dan tidak terinfeski COVID-19.

\section{METODE PELAKSANAAN}

Sesuai dengan tujuan kegiatan ini dilaksanakan untuk meningkatkan pemahaman serta kesadaran peserta (ibu hamil) sebagai upaya pencegahan COVID-19 maka dilakukan dengan teknik penyuluhan. Sasaran kegiatan ini adalah seluruh ibu hamil yang datang melakukan ante natal care (ANC) secara rutin di Balai Pengobatan Swasta Mariana yakni sebanyak 52 orang.

Penyuluhan ini dilakukan dengan mematuhi protokol kesehatan yang ketat. Untuk mencegah terjadinya kerumunan pada saat kegiatan, tim pengabdian masyarakat beserta pimpinan Balai Pengobatan Swasta Mariana memutuskan kegiatan dibagi menjadi empat (4) 
sesi dengan pembatasan jumlah perserta tiap sesinya (10-16 peserta). Selain membatasi jumlah peserta, kegiatan ini juga menjaga jarak antar peserta (1-1, $5 \mathrm{~m}$ ). Peserta wajib menggunakan masker dan tidak dianjurkan membawa anak-anak < usia 10 tahun pada saat kegiatan berlangsung.

Kegiatan pengabdian masyarakat ini dimulai dari (1) studi pendahuluan, kegiatan ini bertujuan untuk menggali permasalahan yang ada di masyarakat, menentukan target kegiatan dan merencanakan solusi atas permasalahan yang ditemukan; (2) izin kegiatan, kegiatan ini berupa meminta izin kepada pimpinan Balai Pengobatan Swasta Mariana dijadikan lokasi penyuluhan dan menentukan jadwal kegiatan, pembagian kelompok kecil peserta penyuluhan, dan memberikan undangan kegiatan penyuluhan kepada para ibu hamil; (3) penyuluhan, kegiatan ini dilakukan berupa memberikan informasi/pendidikan kesehatan tentang COVID-19 dengan topik pengenalan COVID-19, cara penularan, dampak teinfeksi COVID-19 pada kehamilan dan upaya pencegahannya selama hamil, antenatal care (ANC) yang tepat selama pandemi. Tahapan dari penyuluhan ini dimulai dari pemaparan materi, demonstrasi (memperagakan cara penggunaan masker yang tepat, teknik mencuci tangan) (4) refleksi dan penutupan, pada tahap ini tim melakukan refleksi dan diskusi kepada peserta mengenai materi yang telah disampaikan. Pada tahap ini dilakukan sesara interpersonal antara peserta dan pemateri. Pada tiap sesinya pemateri mengevaluasi sekaligus melakukan komunikasi dan edukasi lebih mendalam (1 pemateri melakukan 2-3 peserta per sesinya); (5) Pembuatan laporan pengabdian, tahap ini tim melaporkan hasil kegiatan yang telah berlangsung pada pimpinan Balai Pengobatan Swasta Mariana dan sepakat bersama-sama mempertahankan dan memantau pemahaman dan perilaku ibu hamil dalam upaya pencegahan tertularnya COVID-19.

\section{HASIL DAN PEMBAHASAN}

Penyuluhan dilakukan semenarik mungkin dengan bahasa yang sederhana yang dapat dimengerti para peserta. Para peserta tampak antusias dalam mengikuti kegiatan ini. Hal ini terlihat dari jumlah peserta yang mengikuti kegiatan ini cukup banyak dari 52 ibu hamil yang tercatat di Agustus 2020, terdapat 37 ibu yang mengikuti kegiatan ini. Keantusiasan peserta mengikuti penyuluhan ini disebabkan adanya kesadaran diri dari peserta betapa bahayanya COVID-19 dan kurangnya pengetahuan terhadap COVID-19. Kebutuhan seseorang terhadap informasi dalam memecahkan masalah yang sedang dihadapi merupakan suatu motivasi kognitif (Suryantini, 2003).

Sebelum dilakukan penyuluhan tim memberi kuesioner yang harus diisi oleh para peserta didapati hasil sebagai berikut:

Tabel 1. Persentase Pengetahuan tentang COVID-19 Sebelum Penyuluhan

\begin{tabular}{|c|c|c|c|c|c|}
\hline No & Pengetahuan & & Baik & Kurang & $\begin{array}{c}\text { Jumlah } \\
(\%)\end{array}$ \\
\hline 1 & Penularan COVID-19 & & $35.1 \%$ & $64.9 \%$ & 100 \\
\hline 2 & $\begin{array}{l}\text { Pencegahan penularan COVID-19 } \\
\text { kehamilan }\end{array}$ & selama & $21 \%$ & $78 \%$ & 100 \\
\hline 3 & Penggunaan masker yang tepat & & $41 \%$ & $59 \%$ & 100 \\
\hline
\end{tabular}


Dari tabel 1 didapati seluruh peserta berpengetahuan kurang baik tentang COVID19, dan dari 3 pengetahuan yang digali peserta memiliki pengetahuan yang paling rendah adalah pengetahuan tentang pencegahan penularan COVID-19 selama kehamilan. Pengetahuan merupakan hal yang terpenting dalam menentukan tindakan ataupun perilaku seseorang (Aritonang, 2018), jika seseorang berpengetahuan rendah tentang sesuatu maka dominan memiliki sikap dan tindakan yang kurang juga. Adanya pandemi COVID-19 ini memaksa masyarakat haru banyak mencari tahu tentang penyakit ini guna sebagai langkah untuk pencegahan agar kita tidak terinfeksi.

Menurut penulis rendahnya pengetahuan peserta menimbulkan rasa cemas/takut dalam kehamilan di era pandemi COVID-19. Hal tersebut terbukti pada pretest yang diberikan kepada peserta tentang kecemasan yang dialami oleh peserta. Didapati 80\% peserta cemas dalam menghadapi pandemi COVID-19 ini. Kegiatan penyuluhan ini diharapkan menjadi suatu upaya dalam pencegahan penularan COVID-19 memalui peningkatan pemahaman peserta dan mengurangi kecemasan peserta selama hamil di era pademik. Temuan yang didapati berikutnya pada saat kegiatan adalah terjadinya perubahan tingkat pengetahuan peserta tentang COVID-19 yang dapat dilihat pada tabel berikut ini:

Tabel 2. Persentase Pengetahuan tentang COVID-19 Setelah Penyuluhan

\begin{tabular}{|c|c|c|c|c|c|}
\hline No & Pengetahuan & & Baik & Kurang & $\begin{array}{c}\text { Jumlah } \\
\text { (\%) }\end{array}$ \\
\hline 1 & Penularan COVID-19 & & $86.5 \%$ & $13.5 \%$ & 100 \\
\hline 2 & $\begin{array}{l}\text { Pencegahan penularan COVID-19 } \\
\text { kehamilan }\end{array}$ & selama & $89 \%$ & $11 \%$ & 100 \\
\hline 3 & Penggunaan masker yang tepat & & $91.8 \%$ & $8.2 \%$ & 100 \\
\hline
\end{tabular}

Dari tabel 2 didapati bahwa peserta memiliki pengetahuan yang baik mengenai penularan COVID-19, pencegahan penularan COVIS-19 selama kehamilan, dan penggunaan maker yang tepat. Terjadi peningkatan 50\% pengetahuan yang lebih baik setelah dilakukan kegiatan ini.

Peningkatan pemahaman peserta dikarenakan sebagai hasil kegiatan penyuluhan ini dengan menggunakan teknik pennyuluhan yang diikuti dengan adanya demonstrasi, redemonstrasi, diskusi interpersonal. Penggunaan media merupakan suatu kompenen terpenting dalam suatu kegiatan penyuluhan (Johariyah \& Mariati, 2018). Hasil penelitian yang sama dengan temuan pada kegiatan ini dilaporkan bahwa ada perubahan pengetahuan, sikap dan ketrampilan ibu sebelum dan sesudah diberikan penyuluhan (Kapti et al., 2019). Menurut ada proses yang kompleks terjadi pada saat kegiatan penyuluhan yakni pancaindera yang banyak menyalurkan pengetahuan keotak adalah mata pengetahuan manusia diperoleh dan disalurkan melalui pancaindera yang lain, sehingga penyuluhan dapat dijadikan suatu media untuk menigkatkan pengetahuan dan perubahan perilaku seseorang.

Selain terjadinya peningkatan pemahaman, kecemasan para peserta juga terjadi penurunan sebanyak $12 \%$ menjadi 67.6\%. Penurunan angka kecemasan setelah kegiatan ini. Pemberian pendidikan kesehatan melalui metode penyuluhan mempengaruhi kecemasan. Kecemasan tidak akan terjadi apabila pengetahuan seseorang tersebut cukup-baik. 
Penyuluhan adalah suatu prosesyang bertujuan untuk memberikan pengaruh pada pengetahuan, sikap dan prilaku seseorang ataupun kelompok (Widorini et al., 2017).

Rendahnya penurunan angka kecemasan yang dihasilkan kemungkinan disebabkan adanya perbedaan tingkatan kecemasan para peserta yang sebelumnya tidak diukur. Selain itu, menurut penulis angka kecemasan yang masih tinggi disebabkan COVID-19 begitu cepat penularannya, dan angka kematian yang terus meningkat. Pada saat diskusi tim menemukan pergeseran kekhawatiran dari peserta, tidak lagi proses kehamilan melainkan persiapan kelahiran (keamanan pelayanan kesehatan dan proses menyusui nantinya). Tim terus melakukan penguatan tentang keharusan melaksanakan protokol kesehatan dalam keseharian sebagai langkah pencegahan terinfeksi memberikan kepercayaan diri kepada para peserta bahwa akan tetap sehat dan berjanji akan melaksanakannya.

Melalui kegiatan ini, tim memandang kegiatan ini harus terus dilakukan secara aktif dan berkesinambungan dengan sasaran dengan cakupan lebih besar dan individual seperti suami, anak, dan keluarga. Sehingga masyarakat memiliki pemahaman yang sama, sehingga cegah tular COVID-19 dapat terjadi.

\section{KESIMPULAN}

Dari kegiatan pengabdian masyarakat ini dapat disimbulkan beberapa poin penting, yaitu:

1) adanya peningkatan pengetahuan dan pemahaman ibu hamil dalam upaya pencegahan COVID-19,

2) adanya penurunan kecemasan ibu hamil selama kehamilan di era pandemi COVID-19,

3) perlu dilakukan kegiatan serupa secara berkesinambungan hingga terjadi perubahan perilaku yang lebih baik. Kendala yang didapati pada saat kegiatan adalah, tim hanya melihat dari sisi pemahaman belum sampai pada sisi perilaku. Perlu adanya pemantauan lebih lanjut atas perubahan perilaku setelah dilakukan penyuluhan ini.

\section{UCAPAN TERIMAKASIH}

Penulis mengucapkan terimakasih kepada seluruh pihak yang telah turut melancarkan dan menyukseskan kegiatan pengabdian kepada masyarakat ini yakni LPPM Universitas Sari Mutiara Indonesia, LPPM Universitas Haji Sumatera Utara, Pimpinan Balai Pengobatan Swasta Mariana dan seluruh ibu hamil sebagai peserta kegitan ini.

\section{DAFTAR PUSTAKA}

Aritonang, J. (2018). Peningkatan Pengetahuan Ibu Tentang Imunisasi Pentabio Lanjutan Setelah Pemberian Pendidikan Kesehatan Di Puskesmas Lampaseh Aceh. Jurnal Riset Kesehatan Nasional. https://doi.org/10.37294/jrkn.v2i2.125

Dashraath, P., Wong, J. L. J., Lim, M. X. K., Lim, L. M., Li, S., Biswas, A., Choolani, M., Mattar, C., \& Su, L. L. (2020). Coronavirus disease 2019 (COVID-19) pandemic and pregnancy. American Journal of Obstetrics and Gynecology. https://doi.org/10.1016/j.ajog.2020.03.021

Gugus Tugas Penanganan COVID-19 RI. (2020). Data Covid-19. Beranda Covid19.Go.Id. https://covid19.go.id/ 
Johariyah, A., \& Mariati, T. (2018). Efektivitas Penyuluhan Kesehatan Reproduksi Remaja Dengan Pemberian Modul Terhadap Perubahan Pengetahuan Remaja. Jurnal Manajemen Kesehatan Yayasan RS.Dr. Soetomo. https://doi.org/10.29241/jmk.v4i1.100

Kapti, R. E., Rustina, Y., \& Widyastuti. (2019). Efektifitas Audiovisual Sebagai Media Penyuluhan Kesehatan Terhadap Peningkatan Pengetahuan Dan Sikap Ibu Dalam Pemahaman Pemasangan IUD. Jurnal Ilmu Keperawatan. https://doi.org/10.1017/CBO9781107415324.004

Kementrian Kesehatan Republik Indonesia. (2020). Pedoman Bagi Ibu Hamil, Ibu Nifas, dan Bayi Baru Lahir Di Era Pandemi Covid-19Kementrian Kesehatan Republik Indonesia. In Kementrian Kesehatan Republik Indonesia (Revisi 1). Kementerian Kesehatan RI. http://www.kesga.kemkes.go.id/images/pedoman/Pedoman bagi Ibu Hamil, Bersalin, Nifas dan BBL di Era Pandemi COVID 19.pdf

Liang, H., \& Acharya, G. (2020). Novel corona virus disease (COVID-19) in pregnancy: What clinical recommendations to follow? Acta Obstetricia et Gynecologica Scandinavica. https://doi.org/10.1111/aogs.13836

Luo, Y., \& Yin, K. (2020). Management of pregnant women infected with COVID-19. The Lancet Infectious Diseases, 20(5), 513-514. https://doi.org/10.1016/S14733099(20)30191-2

Pradana, A. A., Casman, C., \& Nur'aini, N. (2020). Pengaruh Kebijakan Social Distancing pada Wabah COVID-19 terhadap Kelompok Rentan di Indonesia. Jurnal Kebijakan Kesehatan Indonesia : JKKI, 09(02), 61-67. https://doi.org/10.22146/JKKI.55575

Qiao, J. (2020). What are the risks of COVID-19 infection in pregnant women? The Lancet, 395, 760-762. https://doi.org/10.1016/S0140-6736(20)30365-2

Saputra, D. (2020). Fenomena Informasi Palsu ( Hoax ) Pada Media Sosial di Tengah Pandemi Covid-19 dalam Perspektif Islam Devid Saputra. Mau'idhoh Hasanah: Jurnal Dakwah Dan Ilmu Komunikasi, 2(1), 1-10. http://journal.iaiagussalimmetro.ac.id/index.php/mauidhohhasanah/article/view/69/40

Schwartz, D. A. (2020). An analysis of 38 pregnant women with COVID-19, their newborn infants, and maternal-fetal transmission of SARS-CoV-2: Maternal coronavirus infections and pregnancy outcomes. Archives of Pathology and Laboratory Medicine. https://doi.org/10.5858/arpa.2020-0901-SA

SUMUT, C.-19. (2020). No Title. Update Data Kasus COVID-19 Di Sumatera Utara, Jumat 28 Agustus 2020. http://covid19.sumutprov.go.id/article/title/update-data-kasuscovid19-di-sumatera-utara-28-Agustus-2020

Suryantini, H. (2003). Kebutuhan Informasi dan Motivasi Kognitif Penyuluh Pertanian Serta Hubungannya dengan Penggunaan Sumber Informasi (Kasus di Kabupaten Bogor, Jawa Barat). Jurnal Perpustakaan Pertanian.

Widorini, D. E., Surachmindari, S., \& Triningsih, R. W. (2017). Pengaruh Edukasi Terhadap Tingkat Kecemasan Pada Ibu Dalam Menghadapi Menopause Di Kelurahan Oro-Oro Dowo Kota Malang. Jurnal Ilmu Kesehatan. https://doi.org/10.32831/jik.v6i1.149

Yang, H., Wang, C., \& Poon, L. C. (2020). Novel coronavirus infection and pregnancy. 
Ultrasound in Obstetrics and Gynecology, 55, 435-437. https://doi.org/10.1002/uog.22006 